Studi di storia 16

\title{
VeneziaeillPeloponneso,
}

992-1718

Indagini storiche

tra territorio, biblioteca

e archivio

Andrea Nanetti

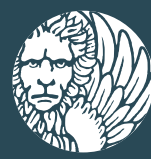

Edizioni Ca'Foscari 
Venezia e il Peloponneso, 992-1718

\section{Studi di storia}

Serie coordinata da

Laura Cerasi

Mario Infelise

Anna Rapetti

16

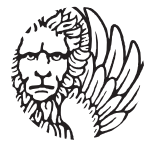

Edizioni

Ca'Foscari 


\section{Studi di storia}

\section{Coordinatori}

Laura Cerasi (Università Ca’ Foscari Venezia, Italia) Mario Infelise (Università Ca’ Foscari Venezia, Italia) Anna Rapetti (Università Ca’ Foscari Venezia, Italia)

\section{Comitato scientifico}

Claus Arnold (Johannes Gutenberg-Universität in Mainz, Deutschland)

Marina Caffiero (Sapienza Università di Roma, Italia)

Giovanni Filoramo (Università degli Studi di Torino, Italia)

Marco Fincardi (Università Ca’ Foscari Venezia, Italia)

Stefano Gasparri (Università Ca' Foscari Venezia, Italia)

Mario Infelise (Università Ca’ Foscari Venezia, Italia)

Vincenzo Lavenia (Università di Bologna, Italia)

Simon Levis Sullam (Università Ca' Foscari Venezia, Italia)

Adelisa Malena (Università Ca' Foscari Venezia, Italia)

Alberto Masoero (Università degli Studi di Torino, Italia)

Rolf Petri (Università Ca' Foscari Venezia, Italia)

Silvio Pons (Università degli Studi di Roma «Tor Vergata», Italia)

Antonella Salomoni (Università della Calabria, Cosenza, Italia)

Enzo Traverso (Cornell University, Ithaca, USA)

Giovanni Vian (Università Ca' Foscari Venezia, Italia)

Chris Wickham (University of Oxford, UK)

\section{Direzione e redazione}

Università Ca' Foscari Venezia

Dipartimento di Studi Umanistici

Palazzo Malcanton Marcorà, Dorsoduro 3484/D

30123 Venezia

studistoria@unive.it

e-ISSN 2610-9107

ISSN 2610-9883

URL http://edizionicafoscari.unive.it/it/edizioni/collane/studi-di-storia/ 


\title{
Venezia e il Peloponneso, 992-1718 Indagini storiche tra territorio, biblioteca e archivio
}

\author{
Andrea Nanetti
}

Venezia

Edizioni Ca' Foscari - Digital Publishing 2021 
Venezia e il Peloponneso, 992-1718.

Indagini storiche tra territorio, biblioteca e archivio

Andrea Nanetti

(C) 2021 Andrea Nanetti per il testo

(C) 2021 Edizioni Ca’ Foscari - Digital Publishing per la presente edizione

\section{(c) (i)}

Quest'opera è distribuita con Licenza Creative Commons Attribuzione 4.0 Internazionale This work is licensed under a Creative Commons Attribution 4.0 International License

Qualunque parte di questa pubblicazione può essere riprodotta, memorizzata in un sistema di recupero dati o trasmessa in qualsiasi forma o con qualsiasi mezzo, elettronico o meccanico, senza autorizzazione, a condizione che se ne citi la fonte.

Any part of this publication may be reproduced, stored in a retrieval system, or transmitted in any form or by any means without permission provided that the source is fully credited.

Certificazione scientifica delle Opere pubblicate da Edizioni Ca' Foscari - Digital Publishing: il testo qui pubblicato ha preliminarmente ottenuto il parere favorevole del Comitato Scientifico della collana in quanto frutto della raccolta di saggi precedentemente pubblicati e appositamente riveduti e aggiornati per la presente edizione.

Scientific certification of the works published by Edizioni Ca' Foscari - Digital Publishing: the text published here has preliminarily obtained the favourable opinion of the Scientific Board of the Series as it is the result of the collection of essays previously published and specially revised and updated for this edition.

Edizioni Ca’ Foscari - Digital Publishing

Fondazione Università Ca' Foscari

Dorsoduro 3246, 30123 Venezia

https://edizionicafoscari.unive.it/ |ecf@unive.it

1a edizione dicembre 2021

ISBN 978-88-6969-544-5 [ebook]

ISBN 978-88-6969-545-2 [print]

Venezia e il Peloponneso, 992-1718. Indagini storiche tra territorio, biblioteca e archivio / Andrea Nanetti - 1. ed. - Venezia: Edizioni Ca' Foscari - Digital Publishing, 2021. -330 p.; $23 \mathrm{~cm}$. - (Studi storia; 16). - ISBN 978-88-6969-545-2.

URL https://edizionicafoscari.unive.it/it/edizioni/libri/978-88-6969-545-2/

DOI http://doi.org/10.30687/978-88-6969-544-5 
Venezia e il Peloponneso, 992-1718

Indagini storiche tra territorio, biblioteca e archivio

Andrea Nanetti

\section{Abstract}

The extraordinary wealth of archival documents, chronicles, travel reports, archaeological sites and monuments, still for the most part to be studied, makes the privileged relationship between Venice and the Peloponnese a key element for the study of Venetian society, with reference to choices made by Venetians in the search for an ethical relationship with the Other in the geopolitical pursuit of their constitutional aim, i.e. far la marchadantia pacifichamente (to trade peacefully). In an almost millenary chronology (992-1718), the Peloponnese - a land on the maritime border between the Ionian and the Aegean Seas, a cultural and commercial link between the Latin-Roman West and the Hellenistic East - is a privileged laboratory for the training of the next generation of interdisciplinary and cross-cultural historians, and for staunch supporters of peace among peoples.

Keywords Republic of Venice. Peloponnese. 

Venezia e il Peloponneso, 992-1718

Indagini storiche tra territorio, biblioteca e archivio

Andrea Nanetti

\section{Sommario}

1 Introduzione 11

2 Il Peloponneso sulle rotte navali tra Medioevo ed Età Moderna

3 Geografia storica delle terre marittime del Peloponneso (secoli XII-XVI)

$4 \quad$ I Veneziani nel Peloponneso bizantino (992-1204) 57

5 La politica veneziana nel Peloponneso subito dopo la Quarta Crociata (1204-1209)

6 L'ampliamento dei diretti domini veneziani nel Peloponneso (secoli XIV-XV)

7 Note storiografiche sulla Messenia veneziana (1207-1500)

8 La sosta a Modone nelle relazioni dei viaggiatori in Terrasanta (secoli XIV-XVI)

$9 \quad$ La vita civile nei territori veneziani di Corone e Modone (1207-1500)

10 Vigne, vitigni, uva, mosto e vini a Corone e Modone (1289-1500)

11 Gli ordini mendicanti nei territori veneziani della Messenia (1209-1500)

12 La comunità ebraica in Modone e Corone (1334-1500) 203

13 Le fortificazioni di Modone

Archivi e biblioteche d'Italia in dialogo con il sito in Grecia 
14 L'isola di Sapienza in dialogo con biblioteche e archivi italiani

15 A mo' di conclusione

Excursus sul patrimonio archivistico e bibliotecario del Regno Veneto della Morea (1684-1718) come fonte per lo studio del Peloponneso medievale

16 Bibliografia 
La straordinaria ricchezza di documenti d'archivio, cronache, relazioni di viaggio, siti e monumenti archeologici, ancora per la maggior parte da studiare, fa della relazione tra Venezia e il Peloponneso un aspetto chiave per lo studio della società veneziana nel suo intento programmatico di far la marchadantia pacifichamente. In una cronologia quasi millenaria (992-1718), il Peloponneso, terra di confine marittimo tra Ionio ed Egeo, cerniera culturale e commerciale tra Occidente latino-romanzo e Oriente ellenofono, è un laboratorio di grandissimo interesse per una storiografia che voglia affrontare con consapevolezza interdisciplinare le relazioni tranculturali dei popoli mediterranei.

Andrea Nanetti ha studiato lo Stato da Mare della Veneta Repubblica per oltre un trentennio in Italia, Francia, Germania, Grecia e Stati Uniti. Ė l'editore dei Documenta Veneta Coroni et Methoni rogata (1999, 2007), del Patto di Sapienza (2009), e della Cronaca di Antonio Morosini (2010), e autore dell'Atlante della Messenia Veneta (2011) e di At the Origins of the Venetian Sea State (2018). Ė inoltre membro del Comitato per la Pubblicazione delle Fonti per la Storia di Venezia (Venezia) e del Direttivo della Fondazione Maniatakis (Atene e Corone).

Università Ca'Foscari Venezia 